\title{
COMPARISON OF SELECTED PARAMETERS OF WET AND DRY TECHNOLOGY OF PLASTERING
}

\author{
Ing. Ďuriš Adrián; prof. Ing. Kozlovská Mária, Ph.D.
}

\begin{abstract}
The construction industry is constantly trying to improve the parameters of buildings construction. The costs, technology, sustainability and speed of construction are currently often a critical aspect for an investor or developer in the choice of. The paper is focused on process form group for finishing works - plastering. In the construction process is mostly used traditional - wet processes realization of plastering. In the construction process are mostly used traditional - wet processes of plastering. But, currently in construction market offers the new dry plastering technologies, which are characterized by shortly realization, elimination of moisture and improving quality. The potential of dry plastering is evaluated in this paper, which is based on a comparison of selected types of traditional wet and dry technology plastering. The aim of this paper is to compare of their constructional, technological and cost parameters.
\end{abstract}

Key words: construction, wet plastering, dry plastering, comparison

\section{INTRODUCTION}

Plaster is a building product used for exterior and interior coating of walls and ceilings. Plastering is very important process to surface finishing of building. Currently, plastering has two types of realization - by hand or mechanically. In term of technology plasters are divided to wet (traditional) and dry ways of technologies. Wet plastering has been used since ancient times. The earliest plaster was usually made as mixture of clay and fur from animals, later began to use lime, sand, cement and water, but at now the most commonly used modern plaster mixtures. Compared to these wet methods of finishes the walls are built dry methods of lining assemblies the walls.

The issue of whether to finish walls with wet or dry plaster has created debate ever since plasterboard came on the scene in the 1940s [1]. This new form of plaster grew in popularity because it could speed up the building process [3]. According to Brinkley [2] as technology advanced, drywall became more durable and readily available. By the 1950s, drywall had surged in popularity as an interior wall material. The product now covers a majority of the interior walls in modern homes.

So, traditional masonry wall constructions may be finishing by dry or wet plastering. Wet plastering is favoured by many because it matches the look and feel of traditional materials, offers better sound-proofing and doesn't cause problems in fixing items to the walls. But facing of masonry walls with plasterboards have advantages too. It offers speedy assembly without drying period or cracks. Dry plastering (in some sources called also dry lining, drywall or plasterboarding) as alternative of surface finishing of masonry walls, frequently used by developers and contractors and now it offers effective realization and improving quality.

Although great efforts are being made at a research level to develop more and more performing plasters, most studies [4], [5], [6] have focused on the optimisation of a different aspects (thermal, environmental, chemical...), but technological and costs issues have not been taken into consideration.

Lucass et al. [7] contend that in the term of the application of sustainability principles in construction encourages the development of materials and products with new functionalities and applications, able 
to improve hygrothermal, thus environmental performance of buildings. In a society with a high growth rate and increased standards of comfort arises the need to minimize the current high energy consumption by taking advantage of renewable energy sources [8].

In the term of thermal properties of the materials of surface layers, i.e., plasters [9] or plasterboards [10] with incorporated phase change materials have the ability to regulate the temperature inside buildings, contributing to the thermal comfort and reduction in the use of heating and cooling equipment, using only the energy supplied by the sun.

In term of technological and costs parameters is known that the market of construction products requires novel products characterized by high energy/environmental performance and, at the same time, by high market competitiveness (in price, energy efficiency, installation features, etc.) and by a long expected service life [6]. This comparison between wet and dry plastering is missing. On the basic of analysis presented in the next part of the article resulted that dry technologies have advantages in term of technological parameters, but in the cost parameters are more profitable wet plasters.

\section{MATERIAL AND METHODS}

Under investigation were selected plastering technologies. From the wet technologies were chosen gypsum plastering and lime-cement plastering, which are the most frequently types of plastering in Slovakia. From the dry plastering it was dry lining technology, which is based on sticking plasterboard on the wall by adhesive mortar.

The potential of dry plastering will take effect especially regarding the uneven wall surfaces, either in terms of verticality wall or its local inequalities across the wall surface (such as for reconstruction). In the case of wet plastering for the elimination of these inequalities must be used more mortar for plastering. It might bring the advantage for dry plastering in the cost parameters. The question is what thickness of plasters is needed apply to wall in order to become dry plastering more effective in term of cost, too. Research method is based on a comparison of selected technological and cost parameters of the wet and dry plastering. Information for research of technological and cost parameters was obtained from data provided by the producents (technological parameters) and cost data from the database Cenkros 4 (cost programme most used in the Slovakia).

\subsection{Gypsum plaster (GP)}

Gypsum plaster is designed solely for interiors. Its advantage, compared with lime-cement plaster, is greater plasticity and less tendency to crack formation. Plaster surface is adjusted by floating or bag rendering, thereby achieving a smooth surface. The advantage of the gypsum plaster is control of the interior humidity, thus contributing to optimal climate. Plaster is manufactured by a plaster mixtures intended primarily for machine processing in a single layer. It is suitable for masonry walls, concrete structures, as well as in a room with moderate humidity load,.

It is very important to meet a technological specification. The wall surface must be good solid, pure and dry enough. Plaster is applied by plastering machine to the prepared substrate in a layer thickness of plaster min. $10 \mathrm{~mm}$, max. $25 \mathrm{~mm}$ in a single layer.

After applying the required amount of material plaster is wall adjust by rod. Any resulting inequalities are also corrected. Processing time (from mixing t to finishing) is $150-180 \mathrm{~min}$. Plaster surface is final adapted after partial solidifying. For larger inequalities or variable plaster thickness is recommended multi-layer processing. The bottom layer levels adjust the inequalities unevenness then is applied top layer to the required thickness. Inside air temperature must be between +5 and $+30{ }^{\circ} \mathrm{C}$. During first 14 days is needed the intensive ventilation. The subsequent adjustments - painting, assembly of other 
devices on the wall is possible only after total curing of plaster, depending on the thickness of the plaster 10 days $/ 1 \mathrm{~cm}$ of plaster. But even after the entry of strength parameters, especially machine application of the plaster (which contains more water) it has limited the progress of work, for example in relation to the installation of drywall ceiling. The built-in moisture in the plaster walls causes plane deformation (deflection) plasterboard ceiling boards.

\section{$2.2 \quad$ Lime-Cement Plastering (LCP)}

Lime-cement plastering have a long tradition and they are the most used in the Slovakia. They are suitable for the interior and exterior. Surface treatment is done by a suitable smoothing trowel. This final surface is reasonably smooth, fine-grained to touch. Lime-cement plasters are suitable for all living spaces also with a higher moisture conditions.

Lime-cement plastering is mechanized or manually applied to the thickness minimum $10 \mathrm{~mm}$, maximum $25 \mathrm{~mm}$ in one layer. After applying the required amount of plaster material is wall adjust by rod. Any resulting inequalities are also corrected. More often however one more layer is applied like fine plaster to achieve a smooth surface. For larger inequalities is recommended multi-layer processing. The bottom layer has to correct the unevenness, and then is applied the top layer to the required thickness. Inside air temperature must be between +5 and $+30{ }^{\circ} \mathrm{C}$. When plastering of multilayer processing plastering are arising to waiting times for hardness or solidification. Depending on the consistency of the plaster and the application method, there is a similar problem with incorporated moisture, as for gypsum plasters, too.

\subsection{Dry Plastering (DP)}

Dry plastering or lining is a modern technique used to create a finish for internal walls. Authors [3], [11], [12] claim that dry lining or drywall is the term used to describe covering of walls by prefabricated construction boards attached to the structure. Dry lining now refers mainly to covering internal walls by plasterboard. According to Brinkley [2] dry lining has several advantages over the wet finish in that it can be installed much more quickly, especially in the case where it is stuck to the walls using a mix of plaster as adhesive.
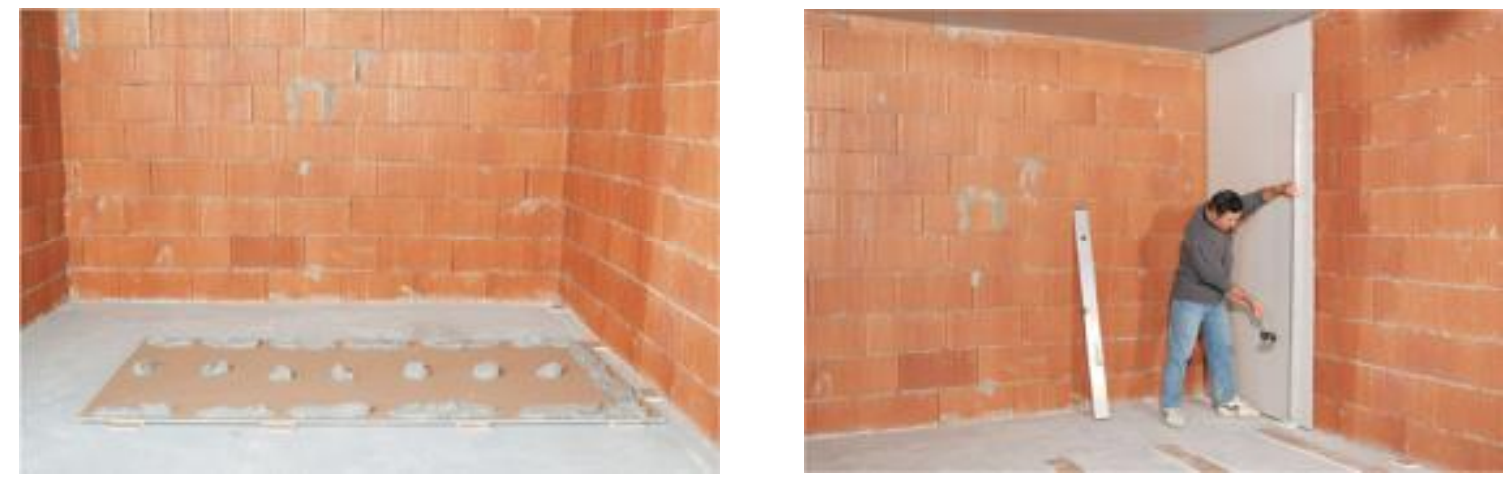

Fig. 1 Application of adhesive to plasterboard [14] Fig. 2 Dry lining, straightening of plasterboard[15]

The most important advantage is effective compensate for any unevenness for a short time, in the required quality and at a reasonable cost. This method is called dot and dab. The fact that dry lining is lighter than its wet counterparts means that the finished construction is lighter and less moisture is introduced into the building structure. Dry lining of partitions also mean that property can be changed to suit the changing needs of a family more quickly [3]. According to [12] conservation of fuel and power are most governments buzzwords these days. Plasterboard also comes in many varieties which, 
without changing methods of construction too much, allow for the introduction of soundproofing, greater fire protection, moisture protection and the protection offered when warm vapour is not allowed to get into voids and condense on colder surfaces.

The disadvantages of dry lining are that it is more difficult to fix things to the wall, and easier to damage. It is also, without the introduction of the correct products, terrible at sound insulation. There is any number of plasterboard fixings available now and with a little forward planning when building a new plasterboard wall or partition additional timbers can be inserted to carry the heaviest of loads [2]. Dry lining has advantages over wet plastering in terms of the speed of the process. The basic structure required for the plasterboard is simple to construct in a short time, the plasterboard can be fitted immediately and the final of skim of plaster dries quickly - allowing for decoration in a shorter space of time [3].

\section{RESULTS AND DISCUSION}

The potential of dry plastering is shown especially in the thicker layers of plaster and plastering wall with uneven surfaces. The analysis of the technological parameters and the cost were investigated in a single-layer plastering thickness of 10 and $25 \mathrm{~mm}$, and the double layer plastering thickness of 30 and $40 \mathrm{~mm}$.

Tab. 1 Comparison of selected parameters of plastering (GP -Gypsum Plaster, LCP - Lime-Cement Plaster, DP Dry Plastering)

\begin{tabular}{|c|c|c|c|c|c|c|c|c|c|c|}
\hline \multirow{2}{*}{\multicolumn{2}{|c|}{ Plastering }} & \multirow{3}{*}{$\begin{array}{c}\text { thickness } \\
\text { Unit of } \\
\text { measure }\end{array}$} & \multicolumn{4}{|c|}{ single-layer plastering } & \multicolumn{4}{|c|}{ double layer plastering } \\
\hline & & & \multicolumn{2}{|c|}{$10 \mathrm{~mm}$} & \multicolumn{2}{|c|}{$25 \mathrm{~mm}$} & \multicolumn{2}{|c|}{$30 \mathrm{~mm}$} & \multicolumn{2}{|c|}{$40 \mathrm{~mm}$} \\
\hline & parameter & & $\mathrm{H}$ & M & $\mathrm{H}$ & M & $\mathrm{H}$ & M & $\mathrm{H}$ & M \\
\hline \multirow{5}{*}{ जี } & $\begin{array}{l}\text { labour } \\
\text { intensity }\end{array}$ & $\mathrm{Nh} / \mathrm{m}^{2}$ & 0,41 & 0,31 & 0,48 & 0,35 & 0,68 & 0,39 & 0,86 & 0,44 \\
\hline & mixing water & $1 / \mathrm{m}^{2}$ & \multicolumn{2}{|c|}{4,24} & \multicolumn{2}{|c|}{10,60} & \multicolumn{2}{|c|}{12,72} & \multicolumn{2}{|c|}{14,84} \\
\hline & weight & $\mathrm{kg} / \mathrm{m}^{2}$ & \multicolumn{2}{|c|}{11,00} & \multicolumn{2}{|c|}{27,50} & \multicolumn{2}{|c|}{33,00} & \multicolumn{2}{|c|}{38,50} \\
\hline & waiting time & day & \multicolumn{2}{|c|}{10,00} & \multicolumn{2}{|c|}{25,00} & \multicolumn{2}{|c|}{30,00} & \multicolumn{2}{|c|}{40,00} \\
\hline & costs & $€ / \mathrm{m}^{2}$ & 7,74 & 8,01 & 13,20 & 12,55 & 15,02 & 14,07 & 21,47 & 19,71 \\
\hline \multirow{5}{*}{ క్తి } & $\begin{array}{c}\text { labour } \\
\text { intensity }\end{array}$ & $\mathrm{Nh} / \mathrm{m}^{2}$ & 0,41 & 0,23 & 0,49 & 0,28 & 0,70 & 0,32 & 0,84 & 0,45 \\
\hline & mixing water & $1 / \mathrm{m}^{2}$ & \multicolumn{2}{|c|}{3,85} & \multicolumn{2}{|c|}{9,63} & \multicolumn{2}{|c|}{11,55} & \multicolumn{2}{|c|}{13,48} \\
\hline & weight & $\mathrm{kg} / \mathrm{m}^{2}$ & \multicolumn{2}{|c|}{14,00} & \multicolumn{2}{|c|}{35,00} & \multicolumn{2}{|c|}{42,00} & \multicolumn{2}{|c|}{49,00} \\
\hline & waiting time & day & \multicolumn{2}{|c|}{10,00} & \multicolumn{2}{|c|}{25,00} & \multicolumn{2}{|c|}{30,00} & \multicolumn{2}{|c|}{40,00} \\
\hline & costs & $€ / \mathrm{m}^{2}$ & 7,66 & 5,88 & 12,04 & 8,90 & 13,50 & 9,90 & 20,31 & 16,06 \\
\hline \multirow{5}{*}{$\hat{\bar{a}}$} & $\begin{array}{l}\text { labour } \\
\text { intensity }\end{array}$ & $\mathrm{Nh} / \mathrm{m}^{2}$ & 0 , & 69 & 0 , & & & & & 69 \\
\hline & mixing water & $1 / \mathrm{m}^{2}$ & 1, & 38 & 2 , & & & & & 76 \\
\hline & weight & $\mathrm{kg} / \mathrm{m}^{2}$ & 2 , & 50 & 3 , & & & & & 00 \\
\hline & waiting time & day & 1 , & 00 & 1 , & & & 00 & & 00 \\
\hline & costs & $€ / \mathrm{m}^{2}$ & 11 & 07 & 11 & 30 & & 57 & & 77 \\
\hline
\end{tabular}

$\mathbf{H}$ - manual process, $\mathbf{M}$ - mechanized process 
The analysis of technological parameters indicates that dry plastering versus wet plastering:

- consumes about $80 \%$ less water,

- reduces the waiting time 10 to $300 \%$ (depending on the thickness of the plaster)

- reduces the weight of the structure by approximately $75-85 \%$ (depending on the thickness of the plaster)

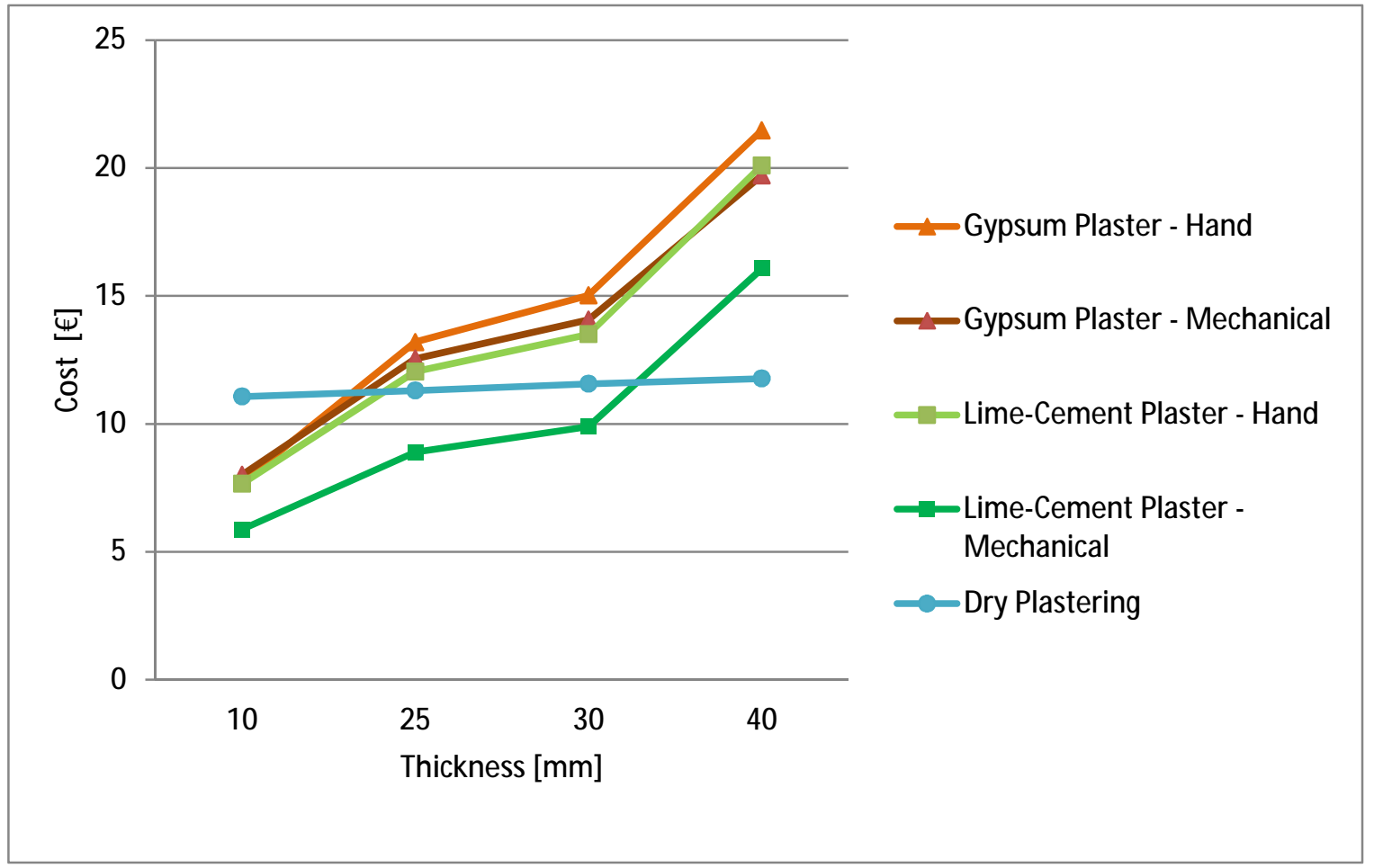

Fig. 3 Cost analysis of selected plastering technologies depending to thickness

In term of cost parameters (Fig.3) is dry plastering more favourable in comparison with manual and mechanized gypsum plastering and manual lime-cement plastering since the layer thickness of $25 \mathrm{~mm}$. Mechanized lime-cement plastering is less favourable at thickness of $35 \mathrm{~mm}$.

\section{CONCLUSION}

Construction market offers many opportunities of wet and dry technologies for performance of construction works. The article was focused on selected plastering technologies and their comparison of the technological and cost parameters. These are significantly influenced by the specific implementing conditions. Based on the collected data, the potential of dry plaster was especially proved for uneven surfaces and thicker plastering, when is needed a more of the material plaster. The analysis of technological parameters indicates that dry plastering against wet plastering consumes about $80 \%$ less water, reduces the waiting time 10 to $300 \%$ (depending on the thickness of the plaster) and reduces the weight of the structure by approximately $75-85 \%$ (depending on the thickness of the plaster). Further research can be focused on experimental studies on inequality parameter in order to determine the effectiveness of the solution.

\section{Acknowledgement}

The article presents a partial research result of project VEGA - 1/0677/14 „Research of construction efficiency improvement through MMC technologies". 


\section{Literature}

[1] NEMATCHOUA, M.K., TCHINDA, R., OROSA, J.A., ANDREASI, W.A.: Effect of wall construction materials over indoor air quality in humid and hot climate, Journal of Building Engineering, volume 3, June 2015

[2] BRINKLEY, M: Wet or Dry Lining?, available: https://www.homebuilding.co.uk/wetplaster-or-dry-lining/

[3] BROWN, J: What is the difference between drywall and plaster?, available: http://home.howstuffworks.com/drywall-vs-plaster.htm

[4] PAVlíK, Z., FOŘT, J., PAVLÍKOVÁ, M., POKORNÝ, J., TRNÍK, A., ČERNÝ, R.: Modified lime-cement plasters with enhanced thermal and hygric storage capacity for moderation of interior climate, Energy and Buidlings, Volume 126, August 2016, available: http://www.sciencedirect.com/science/article/pii/S0378778816303656

[5] CARbONARO, C., TEDESCO, S.,THIEBAT, F., FANTUCCI, S., SERRA, V., DUTTO, M.: An integrated design approach to the development of a vegetal-based thermal plaster for the energy retrofit of buildings, Volume 124, available: http://www.sciencedirect.com/science/article/pii/S0378778816302195

[6] GARG, M., JAIN, N., SINGH, M.: Development of alpha plaster from phosphogypsum for cementitious binders, Construction and Building Materials, Volume 23, Issue 10, 2009, available: http://www.sciencedirect.com/science/article/pii/S0950061809001925

[7] LUCASS, S., SENFF, L., FERREIRA, V.M., AGUIAR, J.L., LABRINCHA, J.A.: Fresh state characterization of lime mortas with PCM additions, Appl. Rheol., 20, 2010 (Article No. 63162)

[8] CUNHA, S., AGUIAR, J., FEREEIRA, V., TADEU, A.: Mortars based in different binders with incorporation of phase-change materials: physical and mechanical properties Eur. J. Environ. Civ. Eng., 2015, pp. 1216-1233

[9] PAVLÍK, Z., TRNÍK, A., ONDRUŠKA, J., KEPPERT, M., PAVLÍKOVÁ, M., VOLFOVÁ, P., KAULICH, V., ČERNÝ, R.: Apparent thermal properties of phase-change materials: an analysis using differential scanning calorimetry and impulse method, Int. J. Thermophys., 34 2013, pp. 851-864

[10] MANHIDILARAS, I., STAMATIADOU, M., KATSOURINIS,D.: Experimental thermal characterization of a Mediterranean residential building with PCM gypsum board walls, Build. Environ., 61 2013, pp. 93-103

[11] Dry Lining Plastering, available: http://prestigeplasteringwilmslow.co.uk/plastering/drylining-plastering

[12] Plasterboard or Dry Lining, available: http://professionalplasteringworcester.co.uk/plastering -services/plasterboard-or-dry-lining/

[13] Drylining and Plasterboarding - How to Dry line a Wall, available: http://www.diydoctor.org.uk/projects/drylining.htm

[14] Application of adhesive to plasterboard, available: http://urobsisam.zoznam.sk/fotogalerie/st avba/uprava-stien-2

[15] Dry lining, straightening of plasterboard, available: http://urobsisam.zoznam.sk/fotogalerie/st avba/uprava-stien-1 